\title{
STABILITY AND CHANGE IN MANAGEMENT ACCOUNTING: AN EXPLORATORY STUDY OF THE USE OF STANDARD COSTING IN AN IRISH MANUFACTURING COMPANY
}

\author{
Martin Quinn, Barbara Flood and Bryan Lynch \\ DCU Business School
}

\begin{abstract}
$\mathrm{T}$

his paper examines the simultaneous presence of both stability and change in management accounting practices by exploring the use of a traditional technique, namely standard costing, in an organisation. The study is framed by literature concerning routines and rules, and the data were gathered by means of a case study. This paper contributes to the literature by providing empirical evidence of the interactions of management accounting routines and rules in a relatively traditional environment. The analysis reveals that change to stable routines can occur but, at the same time, these routines can become further embedded within an organisation.
\end{abstract}

\section{INTRODUCTION}

The methods remain the same. It's just the operation of it that has changed.

The above comment was made by a management accountant at Engineering Ltd (detailed later) when asked about the standard costing system used by the company. This paper attempts to make sense of, in terms of routines and rules, how such simultaneous change and stability in the standard costing system may occur.

Standard costing has been in use as a control system since the late nineteenth century (Kranowski, 1977; Fleischman and Tyson, 1998) and it is often regarded as a 'traditional' management accounting practice. It operates by establishing standard costs, which are estimates of what it should cost to produce an item under efficient operating conditions. The resulting costs are used for cost accumulation purposes 
Quinn, Flood and Lynch

and are compared to actual costs at the end of a period to evaluate efficiency. The need to be able to accurately determine inputs and related costs means that standard costing is best suited to repetitive business processes, typically in the manufacturing sector (Johnson and Kaplan, 1987; Fry, Steele and Saladin, 1998). However, the relevance of standard costing to modern manufacturing has been questioned by many academics (e.g. Johnson and Kaplan, 1987; Bruggeman and Slagmulder, 1995). It is argued that many characteristics of modern organisations (e.g. cost structure, just-in-time (JIT) manufacturing, flexible processes) are incongruent with standard costing (Johnson and Kaplan, 1987; Monden and Sakurai, 1989; Sulaiman and Mitchell, 2005; Zoysa and Herath, 2007). Yet, despite the criticisms and a widespread management accounting change debate in the literature, standard costing remains a popular management accounting practice with high levels of usage (e.g. Clarke, 1997; Fry et al., 1998; Guilding, Lamminmaki and Drury, 1998; Chartered Institute of Management Accountants, 2009). Fry et al. (1998) argue that the continued use of standard costing is due to the absence of superior systems, while Pierce and O'Dea (1998) contend that new techniques are simply being used to supplement rather than replace traditional systems.

The continued use of standard costing as a practice is not the main focus of this research study; rather how it has (or has not) remained a relatively stable management accounting practice in organisations is the issue of interest. Put another way, this study uses an empirical examination of standard costing to address the broader question of simultaneous change and stability in management accounting practices. Much has been written about how management accounting practices can become stable, or routinised, in an organisation (see for example, Burns and Scapens, 2000; Quinn, 2011; van der Steen, 2011). Indeed, routines by definition embody stability (Feldman and Pentland, 2003; Becker, 2004), but change is also possible. However, as noted by Pentland, Haerem and Hillison (2010), empirical research on routines is relatively scarce. Given both the seemingly stable nature of standard costing (as portrayed in text books) and the opening remark in this section which suggests it can change when used in an organisation, it is hoped that this study can provide empirically based interpretations of both change and stability.

The remainder of the paper is structured as follows. The next section briefly reviews the extant literature on organisational and management accounting routines. In particular, the nature and varying dimensions of routines are described and the characteristics of rules are also detailed. The subsequent section describes the research method employed and the case company. The findings and discussion are then presented. In conclusion, some limitations of the present research, as well as implications for future research, are considered.

\section{LITERATURE REVIEW: ORGANISATIONAL ROUTINES AND RULES}

In the past twenty years, an expanding body of research has emerged which seeks to define, understand and conceptualise management accounting change. Many researchers (e.g. Burns and Vaivio, 2001; Sulaiman and Mitchell, 2005) suggest that the publication of Relevance Lost by Johnson and Kaplan (1987) ignited the debate on 
the subject of management accounting change, as it prompted the development and use of 'new' and 'advanced' management accounting techniques and also spurred a re-examination of the role of management accounting and management accountants in organisations. In particular, the advent of Relevance Lost questioned the relevance of management accounting and the ability of traditional practices to deliver and meet the information needs of managers in modern organisations. Indeed, the issue of 'relevance' continues to interest researchers as evidenced by some recent publications (e.g. Otley, 2008; Bhimani and Bromwich, 2010; Scapens and Bromwich, 2010).

Several theoretical approaches have been adopted by researchers to explore different aspects of management accounting change. Broad studies of management accounting systems have tended to use structuration theory (see for example, Macintosh and Scapens, 1990, 1991; Scapens and Roberts, 1993; Jack and Kholeif, 2008; Coad and Herbert, 2009). The new institutional sociology branch of institutional theory has been used to study the convergence of management accounting practices in response to such external influences as political pressures, regulatory changes and cultural factors (see for example, Collier, 2001; Modell, 2003; Seal, 2006; Tsamenyi, Cullen and Gonzalez, 2006; Nor-Aziah and Scapens, 2007). Indeed, various institutional approaches have been utilised by management accounting scholars in recent years (see for example, Soin, Seal and Cullen, 2002; Dillard, Rigsby and Goodman, 2004; Siti-Nabiha and Scapens, 2005; Tsamenyi et al., 2006; Lukka, 2007). In particular, the concepts of routines and rules from old institutional economics (OIE), have been embraced as a way of interpreting change (and/or stability) in management accounting practices (see for example, Burns and Scapens, 2000; Quinn, 2011; van der Steen, 2011). Consequently, as change and stability in a management accounting practice is the focus of the current study, the concepts of routines and rules are utilised to provide an appropriate theoretical base.

A particularly useful starting point in an exploration of routines and rules in management accounting is the work of Burns and Scapens (2000). They define routines as 'the way things are done' $(2000$, p. 5), which can be contrasted with rules, 'the ways things should be done' (2000, p. 6). A detailed account of Burns and Scapens (2000) is not given here, save to say that their framework proposes that through the interactions of routines and rules over time, relative stability in management accounting practices can be explained. Change is also possible, although Burns and Scapens suggest that any such change is more likely to be evolutionary in nature, unless some 'major external change' is experienced (2000, p. 13). However, Burns and Scapens' (2000) study did not set out to explicitly describe the exact nature or dimensions of routines and rules. Indeed, a precise understanding of such phenomena is still elusive and there have been many calls for further empirical research (see for example, Pentland et al., 2010; Quinn, 2010, 2011). The following subsections provide an overview of the contribution of a number of researchers to date to the efforts to better understand the nature of routines and rules.

\section{Organisational Routines}

Many scholars have provided useful contributions to the debate concerning the nature of routines (see for example, Feldman and Pentland, 2003; Becker 2004, 2005; Pentland and Feldman, 2005, 2008; Hodgson, 2006, 2008; Pentland, 2011). A common theme 
in much of this work is the conceptualisation that routines have two dimensions; in other words, they have both an 'action' and a 'structural' element. For example, Winter (1995, pp. 169-170) distinguished between a 'routine in operation at a particular site' and a 'routine per se - the abstract activity pattern', denoting routines as having more than one 'layer'. In summarising the organisational literature, Becker (2005) described the two layers of routines as: 1) an observable surface layer, and 2) an underlying generative layer which cannot be observed. While the generative layer is subject to constant minor changes, which may give rise to multiple surface layer performances of a routine, the core 'purpose' of the routine remains the same (Becker, 2005; Pentland et al., 2010). Similarly, Feldman and Pentland (2003, p. 101) state that 'organisational routines consist of two aspects' or dimensions, namely (1) the ostensive dimension and (2) the performative dimension. They contend that the ostensive dimension of a routine 'may have a significant tacit component' which moulds the perception of what the routine is and 'may exist as a taken-for-granted norm' (Feldman and Pentland, 2003, p. 101). They suggest that 'the ostensive incorporates the subjective understandings of diverse participants' (Feldman and Pentland, 2003, p. 101) and they describe it in later work as 'abstract, cognitive regularities and expectations that enable participants to guide, account for and refer to specific performances of a routine' (Pentland and Feldman, 2008, p. 286). In contrast, the performative dimension of a routine is 'the specific action(s) taken by people' (Feldman and Pentland, 2003, p. 102) 'at specific times, in specific places' (Pentland and Feldman, 2008, p. 286).

More recently, Pentland (2011, p. 281) outlines four characteristics of routines, which he states 'provide ... an easily applicable test of whether a given phenomenon qualifies as an organisational routine':

1. Routines are repetitive.

2. A recognisable pattern of action occurs.

3. The actions are interdependent.

4. Multiple actors are involved.

While these characteristics may act as a useful test to ascertain whether or not observed actions may constitute a routine, the unobservable component of routines - the abstract patterns which underlie actions - must also be acknowledged (Feldman and Pentland, 2003; Becker, 2005; Pentland, 2011).

Volkoff, Strong and Elmes (2007, p. 839) propose that a dimension of a routine may be embedded in technology 'in the form of system-executed transactions - sets of explicitly defined steps that require specific data inputs to automatically generate specific outcomes'. It is clear that many management accounting tasks might be described in this way (e.g. product costing, budgeting and variance analysis) and it is interesting that Volkoff et al. (2007) contend that this 'material' dimension of routines, as they term it, is different from the ostensive dimension as, rather than being 'idealized and abstract', it is 'concrete and specific' (Volkoff et al., 2007, p. 840). This point is revisited in the next section.

Englund and Gerdin (2008, p. 1131) refer to a 'conceptual disparity' in studies concerning routines in management accounting, where some view management 
accounting systems as modalities (i.e. structures) which are drawn on to produce practices, whereas others view the systems as recurrent practices (i.e. actions). They argue that combining both conceptualisations in the same study not only creates confusion, there is also a risk of "social structure and action becoming conflated and potentially we may draw erroneous conclusions about structural change and stability' (Englund and Gerdin, 2008, p. 1131). However, as outlined above there is considerable support in the literature for viewing management accounting routines as having a dual nature, comprising both structural and action dimensions. Thus, for the purposes of the current study it is proposed that management accounting practices may be considered routinised in many organisational contexts, and can be conceived as both observable actions (performative dimension) and underlying abstract patterns (ostensive dimension).

\section{Organisational Rules}

As outlined above, Burns and Scapens (2000, p. 6) define rules as 'the way things should be done' and suggest that rules are more formal in nature than routines. Although they do not state it explicitly, they seem to imply that rules are more likely to be written and precede routines. Since the work of Burns and Scapens (2000), there has been limited examination of rules within management accounting (an exception is Oliveira, 2011) as the majority of empirical studies in the literature have tended to focus on routines (see for example, Quinn, 2011; van der Steen, 2009, 2011). The emphasis on routines as opposed to rules may be due to the fact that, as proposed by Pentland and Feldman (2005), rules are conceived as artefacts of routines. They argue that while any artefacts of routines may be thought of as influencing the performances of routines, there will always be 'open' contextual factors which may limit the potential to actually follow what the rules say (Pentland and Feldman, 2005, p. 797).

Hodgson (2006, p. 18) describes rules as 'socially transmitted and customary normative injunctions or immanently normative dispositions, that in circumstances $X$, do $Y^{\prime}$. This definition begins to convey the more rigid or fixed nature of rules versus routines. Reynaud (2005) also notes a key difference between rules and routines: rules are arrangements awaiting interpretation, whereas routines are rules already interpreted. If a routine is an interpretation of a rule, a question arises on whether the 'interpretation' may be conceptually similar in nature to the ostensive routine as proposed by Feldman and Pentland (2003). However, as noted by Oliveira and Quinn (2012) and as outlined in the previous section, a routine by definition requires repetition. Thus, an interpretation of a rule could not alone be equated to the ostensive dimension of a routine as no repeated actions have yet occurred. As repetition is often associated with management accounting practices, it might be argued that rules (which do not have a repetitive element) may be less important that routines in studies of such practices. However, as noted by Oliveira and Quinn (2012), some management accounting tasks may never actually become routines, as insufficient repetition occurs; thus there may be a 'rule' which guides how the particular task is to be done. Furthermore, Oliveira and Quinn (2012) propose than rules are potentially important components in the eventual formation of routines. This is not to suggest that rules are the only factor which may determine 
the eventual routines, nor that rules are a fixed or unchanging phenomenon (see also Morgen and Olsen, 2011).

Rules can be considered to be either formal or informal. In brief, a formal rule is typically codified in some way, for example traffic rules, whereas an informal rule is more constitutive in nature although it may become regularised and/or codified over time (Searle, 2005). Oliveira and Quinn (2012, p. 20) avoid this formal/ informal classification by contending that rules are cognitive structures which 'have been accepted by organisational members'. In the current paper, we also avoid any informal/formal distinction of rules, instead focusing on the notion that rules are essentially un-interpreted initially, but form cognitive structures in actors' minds that may, over time, result in routines being formed. According to Oliveira and Quinn (2012), an important step in how these cognitive structures (i.e. rules) may become routines over time is the interaction with (and reinforcement by) the 'material routines' of Volkoff et al. (2007), as outlined earlier. Volkoff et al. (2007) view the material dimension of routines as the hard-coding of the underlying rules into information technology (such as enterprise resource planning (ERP) systems). Although Volkoff et al. (2007) do not explicitly use the term 'rules' in their discussion, their definition that 'organisational routines are embedded in the ES [enterprise system] in the form of system-executed transactions - sets of explicitly defined steps that require specific data inputs to automatically generate specific outcomes' (Volkoff et al., 2007, p. 839) implies that they are referring to rules. The reasoning for this is twofold: (1) these material 'routines' are intended to define transactions and their sequence, and (2) on their own, such systems-embedded phenomena do not meet the essential criteria of a routine as set out earlier (see Pentland, 2011). Although these material routines may be conceptually more akin to rules, we adopt the term 'material routines' here as used by Volkoff et al. (2007).

In summary, whereas repetition is deemed an essential feature of routines, recurrence is not necessary for rules. However, as put forward by Burns and Scapens (2000), and more recently by Oliveira and Quinn (2012), rules may be an essential component in bringing about change to practices, such as those within the domain of management accounting. Furthermore, rules are also important to underpin routines in a more formal way (see Oliveira and Quinn, 2012), as well as guiding actors when practices have not become routinised. The case company, which is featured in this paper and is detailed in the next section, experienced new rules in the form of a newly implemented ERP system, thus making rules an essential feature of the analysis. Furthermore, the nature of the business sector implied some traditional (and routinised) management accounting practices were in use. Thus, the concepts of both routines and rules are utilised in our analysis.

\section{RESEARCH METHOD}

Having outlined some useful theoretical constructs around routines and rules, this section now turns to the empirical case study. The research approach is outlined first, followed by some details regarding data collection and analysis. The section concludes by presenting details regarding the case company. 


\section{Research Approach}

The objective of this study is to examine the presence of stability and change in management accounting practices by exploring, through the lenses of routines and rules, the use of standard costing in a manufacturing company. While routines and rules have received considerable attention in the literature, there is still a need, as noted by Pentland (2011), to tease out their complexities by the conduct of more real life studies. As a case study approach facilitates the exploration of phenomenon in a real life context, it was deemed the most appropriate means of data collection for this study (Atkinson and Shaffir, 1998; Yin, 2003).

Scapens (2004) identifies four possible roles for researchers in a case study. In this study, a visitor role was adopted. Several visits to the case site were made and the empirical data were collected primarily through semi-structured interviews. Given the exploratory nature of the study, interviews with four key participants in the company were conducted, namely the managing director, a management accountant, an assistant management accountant and a financial analyst. All interviews were digitally recorded with the permission of the participants. All participants were forwarded an outline interview guide in advance of each interview. This guide was divided into three main sections:

- The purpose/role of management accounting in the organisation

- Change(s) to management accounting

- The operation of, and changes to, standard costing at the organisation

The first two sections focus on the role, context and uses of management accounting practices generally in the case company, while the third part of the interviews particularly examined the uses of the standard costing system. In addition to interviews with the key participants, access to company documentation and files was forthcoming to support interview data.

In keeping with other studies of organisational/management routines, the interview transcripts and other data were analysed using an interpretive approach. This involved examining data for evidence of both routines and rules. In particular, the process of how certain management accounting practices were performed was extracted from the data to determine whether or not they could be classified as routinised as per the four criteria of Pentland (2011). In turn, if management accounting practices were deemed routinised, then data were analysed for evidence of any changes to the practices over time and how rules came into play in these changes.

\section{Case Company: Background}

An electrical product manufacturing company, referred to here as 'Engineering Ltd', was selected as the case site for a number of reasons. First, access was likely to be forthcoming through personal contacts of the authors. Second, the company operates in a business sector which implies that its management accounting practices are likely to be more traditional and less subject to radical change (see later for more detail). And, third, as the company had updated its management information systems using an enterprise resource planning suite (namely SAP), there was the 
potential to find evidence of change to management accounting practices and to the role of management accounting in the organisation (Granlund and Malmi, 2002; Scapens and Jazayeri, 2003). This implementation of SAP had the potential to alter standard costing, as well as how standard costing data were collected, stored and updated. Having made initial contact with Engineering Ltd, access was agreed for an exploratory study of management accounting practices at the company, with a particular focus on standard costing.

Engineering Ltd was established in the late 1970s, has an annual turnover in the range of $€ 50-€ 100$ million and employs approximately 300 people. It is a subsidiary of a European electrical product manufacturing group. Since 2005, the European group has been wholly owned by an Indian multinational, which itself is part of a United States (US) global conglomerate group. Engineering Ltd manufactures a range of electrical products which are sold globally. Due to the specialised nature of the products and a repetitive production process, the company has always used standard costing. The standard costing system has recently been embedded into the SAP software, which was installed at the instigation of the US parent. Engineering Ltd's costing system focuses on the direct costs of raw materials and production labour and, like all companies in its sector, the company prices products based on direct costs plus a margin. As the standard direct costs are the basis of prices offered to customers, standards are revised on a monthly basis - a feature of the new SAP system is an inflationary adjustment to standard costs for projecting prices for products that are typically manufactured within one month. This monthly revision of standards also permits an accurate evaluation of direct materials usage and wastage, which is important as the materials (primarily metals) make up a significant proportion (approximately 70 per cent) of total costs. The cost structure of the company has remained very stable over the years with direct labour representing approximately 20 per cent and overheads being approximately 10 per cent of total costs.

Before describing the standard costing system of Engineering Ltd, it is important to note that, given the objective of the study, we place less emphasis on the intricacies of the technique itself and more on its routinised nature, and how this routinised nature may change (or remain relatively stable). Further, while at the outset of this study we contend that it is reasonable to term standard costing a routine in Engineering Ltd, the case evidence will be evaluated in light of Pentland's (2011) defining characteristics of a routine in order to evaluate the appropriateness of our contention.

\section{FINDINGS}

It was clear from evidence presented in the interviews that management accounting plays, and is perceived to play, an important role in the operation and management of the company. Reports produced by the management accounting department are used throughout the organisation for cost management, pricing and decision-making purposes; as the managing director comments: 'I would see the role of management accounting as being very important ... their [the management accounting 
department's] work really does span the entire organisation.' Members of the management accounting department were anxious to explain how their activities are embedded across the organisation and provide 'information that drives the business' (management accountant). Furthermore, the role of management accounting in Engineering Ltd embraces more than the traditional product costing role and is responsive to the needs of the business, as conveyed by the quote below:

As our raw materials consist mainly of oil, copper, aluminium and steel, we generally have a lot of working capital tied up in stock (approximately $€ 4.5$ million). So getting our stock valuation correct is very important, but I have also seen a big move in focus to cost control in the last 18 months. With the slowdown generally in the economy, controlling costs is paramount if you want to remain competitive. ... The majority of our time is focused on managing costs. That means understanding where they come from, why, and how we can reduce or eliminate them in the future. ... It's no good capturing costs correctly if they are spiralling out of control. Knowing your costs and their behaviour means we can provide better information for making decisions (assistant management accountant).

It is acknowledged that the role of management accounting has changed somewhat over the years. As the management accountant explained, in the past the management accounting function produced reports but did not necessarily participate in subsequent decision making. Currently, the accounting function is at the heart of decision-making activities, as the management accountant is a part of the core management team. He attends all management meetings, assisting in the interpretation of the accounting information and participating in shaping the future direction of the business. This increased importance of management accounting at Engineering Ltd is by and large due to the fact that the company operates in an increasingly competitive environment, which requires a much shorter production cycle than before and requires much greater interaction and cooperation between all departments concerning decision making:

The whole organisation must be on its toes to ensure production runs smoothly. Working in tandem means everyone must communicate. That means for us in management accounting we have to keep up to date with production managers ... and we have to be fully aware of what is happening plant-wide. When you are aware of what's happening in a particular department you can provide them with better or 'tailored' information (management accountant).

The evolved role of management accounting is accepted and embedded in the organisation, as the managing director comments:

Now I expect the management accountants to communicate with me and all other members of staff on any issue that arises. Accountants possess too much knowledge to work in silence. Their information is priceless in modern organisations.

In terms of what has prompted the changed role of management accounting in Engineering Ltd, a number of factors can be identified from the interview data. First, as outlined above, the competitive environment required increased response times 
and enhanced cost management, which necessitated changes in the information generated by the management accounting department and the interactions of the management accounting department with other units in the organisation. Second, the organisation became part of a large global group in recent years, which has resulted in increased reporting requirements to group headquarters. As the management accountant explained, group headquarters are not interested in summary information; they conduct ongoing detailed interrogation of financial data and they expect the management accounting department to be able to explain and analyse all information. This requires the management accounting staff to constantly interact with units across the business, as they need to fully understand what is going on. This finding is consistent with that of Yazdifer, Zaman, Tsamenyi and Askarany (2008), who reported that becoming part of a multinational group can increase the demands on management accounting and prompt change. A third facilitator of change in Engineering Ltd has been the introduction of the SAP system, which was required to meet group reporting demands. The amount of information maintained by the SAP system enables the management accounting department to produce reports which examine quality, capacity and productivity and are more useful to the various units of the business: 'it has changed the way we work and the reporting capabilities of the management accounting department ... it means we can add more to the firm' (assistant management accountant). This is also consistent with much prior research (e.g. Booth, Matolcsy and Wieder, 2000; Caglio, 2003; Scapens and Jazayeri, 2003; Burns and Baldvinsdottir, 2005).

While change was experienced regarding the role of management accounting in the decision-making processes of the organisation, standard costing remained in use as the key cost accumulation and control practice. In many ways, this is not surprising as Engineering Ltd has not experienced alterations in its manufacturing processes or cost structure, two perceived catalysts for change in management accounting practices (see for example, Otley, 1985; Johnson and Kaplan, 1987; Bruggeman and Slagmulder, 1995; Jazayeri and Hopper, 1999). Additionally, standard costing remains prevalent in the industry, given the widespread use of cost plus pricing and the subsequent need to control costs to protect margins. Combined, these factors create an environment where the continued use of standard costing is likely. Managers across Engineering Ltd demand information for accurate product pricing and cost control and their standard costing system, through the establishment and revision of standards and the calculation and investigation of variances, can meet these information needs. Thus, accuracy of standard setting and meaningful variance analysis are as important as ever:

I would say here in Engineering Ltd that, due to global competition, the basics need to be better than ever to succeed. And that means for us having a very accurate standard costing system so we can quote products and get business that gives us an adequate margin. Also, standard costing allows us to track and monitor costs, which is of increased significance in very competitive markets. Our margin really depends on us keeping to the quoted cost the sales guys give customers. So accurate product costing, and actually keeping in line with those costs, is a huge part of what we do in this department (management accountant). 
However, while some elements of the standard costing system (i.e. setting standards, and so on) have remained stable, others have changed: 'The methods remain the same. It's just the operation of it that has changed' (assistant management accountant). Ultimately, the introduction of the SAP system has rejuvenated the reporting capabilities of standard costing as is evident in the following quotes:

The amount of data it holds means I have access to information I never had before. And that means we can create reports that we simply couldn't with our old IT [information technology] system. ... Now I have information on every aspect of the company (management accountant).

SAP is even making our standard costing system better, with the database of information it holds. We are getting reports of greater detail on a wider variety of issues. Standard costing is more important in Engineering Ltd than ever before. It's amazing how SAP has improved the system (financial analyst).

The way the whole standard costing system works here means you have a huge amount of interaction with the engineering department. ... With SAP, interaction is more efficient; you are not running back and forward (management accountant).

The data contained in SAP produces reports that all inter-link. ... We can use reports than concern things like quality, capacity and productivity when we are examining variance reports. ... SAP allows variances to be put in perspective. It's no good keeping to standards if your quality goes out the window (management accountant).

As well as facilitating more relevant reports, the introduction of SAP also improved the timeliness of information outputs so that it is 'now as close as you'll get to live data streaming' (assistant management accountant). Furthermore, since the introduction of SAP, standard costing reports are more widely available and more staff can access the information system. This has fostered a clearer understanding of standard costing within the broader organisation:

Since the reports are available throughout the firm, standard costing is more accepted. People in other areas know what it's all about. They understand how important it is to have an accurate system. That makes our jobs as management accountants easier when we are ringing up annoying people for information, because before they didn't really care but now they know it impacts on them too, so they are much quicker with getting back to us. It's giving standard costing justification in the company (management accountant).

Additionally, how standard costing is used post-SAP facilitates greater organisational interaction and communication and shapes the way the management accounting department interfaces with other departments in the organisation:

Well since the reports generated from the standard costing system are now being used throughout the company, I suppose you could say the standard costing is tying the organisation together. And this is what is forcing more communication with the accountants. ... The variety of reports means more people are indirectly using the 
Quinn, Flood and Lynch

system, and this means more people are calling on the accountants for their advice (financial analyst).

As portrayed thus far, there have been some changes in the way standard costing is used at Engineering Ltd post-SAP. However, there was never any consideration of moving away from standard costing for the purposes of planning, control and decision making. As previously outlined, Engineering Ltd operates in a market where basic commodity-type raw materials are used in the manufacturing process. And, given that these raw materials constitute about two-thirds of the final product cost, the market creates a level playing field for pricing by adding a margin to the direct costs of production. The following quote from the assistant management accountant conveys the market scenario quite well:

We operate a simple cost plus system, but so does the whole market. When we quote a price, that price is basically the standard costs plus a margin. Then out of our margin we pay our overheads. That's how the market works [for] our particular goods.

Thus, standard costing is at the heart of management accounting and decision making at Engineering Ltd. There is some evidence of the evolving role of management accountants (which is not the key focus of this study), and there is clear evidence of continuity of traditional management accounting practices, namely standard costing. Standard costing has been used since the company was established over 30 years ago, and while the fundamental operations of the technique remain unchanged, if we dig deeper some change in the standard costing practices have taken place. Even following the introduction of SAP, the centrality of the standard costing system within Engineering Ltd seems assured:

We are moving into an environment that is getting tougher and tougher to survive in. That means an increasing focus on working capital and cash flow management just to keep going. These fundamentals may be out of fashion at the moment, but as economies tighten and more businesses go to the wall the basics will come back to being management's first thought, you know, like maintaining margins and controlling costs. ... In tough times you have to get back to the fundamentals of running a business. And the accountants harbour these fundamentals, so management accounting is getting more and more important, and that's not going to change (managing director).

With competition growing like it is, a big emphasis will be placed on maintaining margins and containing costs and that means our work will become even more important. ... And with that being the focus for us now into the future, we'll hang on to standard costing (management accountant).

In summary, Engineering Ltd, although experiencing organisational change in terms of both a new parent company and a new ERP system, portrays a relatively stable set of management accounting practices. In particular, the continued use of a traditional management accounting technique (i.e. standard costing) seems to fit well with both the company's cost structure and the nature of the industry. Therefore, substantial changes to management accounting were not evident. It could be argued that standard costing is sufficient for the needs to Engineering Ltd and that 
change is unlikely. However, this does not paint a complete picture. The next section analyses the story from Engineering Ltd in terms of management accounting routines and rules, and conveys how change and stability go hand in hand.

\section{DISCUSSION}

The previous section depicts management accounting at Engineering Ltd as being grounded in standard costing (a traditional management accounting practice). To an external observer, it would be all too easy to conclude that management accounting practices have not changed. This would, of course, not give the full picture of the complex actions and interactions that in fact constitute the constant development of management accounting practice within the organisation. Ultimately, change to management accounting practices did occur, but in a way which supported the existing routines (Burns and Scapens, 2000), while also adapting to new material routines as introduced by the SAP software. The remainder of this section focuses on the analysis of the practice of standard costing at Engineering Ltd, using the theoretical constructs of routines and rules which were presented earlier in the literature review. This analysis aims to provide an interpretation of the elements of stability and change regarding the use of standard costing at Engineering Ltd which were outlined in the Findings section above.

\section{Stability}

As noted previously, Engineering Ltd has always used standard costing and thus, at the outset of this study, it had been assumed that the tasks around standard costing at the company could be termed 'routine'. Based on the empirical data presented in the Findings section of the paper, we can now conclude that standard costing is indeed a routinised practice. Taking Pentland's (2011) defining characteristics of routines, standard costing at Engineering Ltd readily satisfies each:

- Repetitive - standard costing has been in use for more than 30 years on a continuing basis.

- Recognisable pattern of action - while there may have been hundreds of standard costs and reports prepared each month/year for varying reasons, an overall pattern of action can be identified.

- Interdependent - several examples of how standard costing is used as an input for further decision making were revealed.

- Multiple actors - the empirical data presented in the previous section highlighted how standard costing information is widely dispersed and utilised by many actors.

Given the apparent steadfastness of standard costing at Engineering Ltd, we contend that we could describe these routines as being institutionalised (Burns and Scapens, 2000). Almost 90 per cent of total costs in Engineering Ltd comprise materials and labour, with materials consisting predominantly of market-priced commodities. 
Quinn, Flood and Lynch

This business context creates an environment in which a traditional management accounting technique is not only technically sufficient and meets the informational need of managers, but also over time has become the tacitly accepted way of doing things for management accountants and managers at the company. This environment fosters little motivation or need to adopt some of the 'newer' management accounting techniques and thus a strong, stable and potentially institutionalised set of routines was developed and maintained. Prior literature indicates that such routines are unlikely to undergo major change except in the case of external shocks or internal power structures (Burns and Scapens, 2000). Burns and Scapens (2000) describe a takeover as an example of an external shock which could cause existing routines to become undone. In the case of Engineering Ltd, a takeover did occur in 2005 but the new owners were a larger multinational in the same industry. As a result of the takeover, the SAP software was implemented, leading to greater interaction between standard costing routines and other organisational routines (Feldman and Pentland, 2003; Pentland, 2011). Although both the takeover and the information systems change provided potential for large-scale change in management accounting routines, on the surface this did not happen. In other words, despite the potential for change, the ostensive routines around standard costing appear to have remained quite stable. However, this does not mean change cannot occur. Indeed, Burns and Scapens (2000, p. 22) state 'change and stability are not mutually exclusive processes' and so the next subsection seeks to identify aspects of change.

\section{Change}

Above we have established that standard costing (as a routinised management accounting practice) is deeply engrained at Engineering Ltd and the ostensive routines around standard costing are quite rigid and taken for granted. The performative dimension of these same routines may (or may not) be the same as the ostensive dimension (Feldman and Pentland, 2003). Given the long history of standard costing at Engineering Ltd, it is likely that all actors (management accountants and others) share a commonly accepted perception (Feldman and Pentland, 2003) of what constitutes routines, i.e. they understand and accept the general principles of standard costing as the way things are done (the ostensive routines). At the same time, the fact that the ostensive routines are understood, accepted and unquestioned does not mean that there are strict codified procedures as to how to perform these routines. Thus, actors may not perform the routines in a strict, rulelike, unconscious way (Feldman and Pentland, 2003). Over time, however, and as outlined below, the interaction of the ostensive and performative dimensions of a routine can maintain, modify or create routines, while at the same time providing a guiding or reference point for behaviour (Feldman and Pentland, 2003).

The case evidence suggests that the performative routines and ostensive routines associated with standard costing in Engineering Ltd were similar. We base this observation on a number of facts:

- Standard costing had always been practiced at Engineering Ltd

- Standard costing was incorporated into their legacy systems

- The relatively stable nature of Engineering Ltd's operations 
While the legacy system referred to by the management accountant may have had standard costing practices of the company incorporated as material routines (i.e. within the program code), this cannot be verified as this system had since been replaced by SAP. However, all interviewees recounted how important SAP was to the continued (but changed) use of standard costing at the company. Indeed, prior literature has highlighted that the introduction of information systems such as SAP can bring accompanying change to management accounting (Scapens and Jazayeri, 2003). At Engineering Ltd, the introduction of SAP not only encompassed the ostensive dimension of existing routinised standard costing practices, but also introduced new material routines within the SAP configuration (Volkoff et al., 2007). As management accounting staff at the company became familiar with the capabilities of SAP, these capabilities (embodied in the software as material routines) brought about change in standard costing practices. In other words, as the standard costing capability of SAP was utilised, new performative routines emerged over time, which were based on existing ostensive routines and new rules. For example, SAP resulted in 'new' performative routines such as more detailed and timely cost and variance reporting routines, as well as more regular updating of standards by management accountants. As a result of SAP, as one management accountant put it, 'standard costing is now more accepted.' This can be explained by the relative similarity between the existing ostensive (and deeply embedded) routines around standard costing and the supporting material rules within SAP. These material routines, although eventually bringing about new ways of doing things (performative routines), solidified, formalised and distributed what were already accepted and taken-for-granted routines. Yet despite the apparent post-SAP stability and broader acceptance of standard costing as a routinised management accounting and organisational practice at Engineering Ltd, change to those same practices did occur. This finding echoes the work of, for example, Burns and Scapens (2000) and Feldman and Pentland (2003), who both clearly outline how change and stability go hand in hand. It also suggests that there may be multiple levels at which routines can be analysed, as suggested by Vromen (2011). More specifically, at a high level of analysis we could say that routines in Engineering Ltd have not changed as standard costing is still performed. However, if we drill down to a lower level of analysis, we have revealed how aspects of the tasks and components within standard costing have changed (see also Pentland et al., 2010).

In summary, as originally suggested by Burns and Scapens (2000), the routinised nature of management accounting practices may offer potential interpretations of why stability is often a common feature in a management accounting context. However, as our study of standard costing, which is a traditional (and stable) management accounting practice, has shown, change to highly routinised practices is always possible. Based on the evidence from Engineering Ltd, we contend that change to existing routines is more likely to occur when new rule-like structures (material routines in this case) emerge. Eventually, through repeated action these material routines may create new routines; in other words, in the case of Engineering Ltd new ways of doing old tasks materialise. 
Quinn, Flood and Lynch

\section{CONCLUSIONS}

The purpose of this paper was to explore, in routines and rules terms, how a traditional and routinised management accounting practice, such as standard costing, can be deeply embedded (i.e. stable), but yet also encompass change. The evidence from Engineering Ltd, albeit a single exploratory study, offers some insights into the dynamics of existing routines and how the introduction of new material rules may potentially support and solidify these routines. However, as was outlined, the nature of Engineering Ltd's industry sector is one which has a relatively stable cost structure and is unlikely to require the application of complex or 'new' costing techniques. Thus, not unexpectedly, we found that changes, although present, were not of a revolutionary type (Burns and Scapens, 2000). Research in more dynamic business sectors would be useful to further enlighten the interactions of existing routines and new (material) rules.

The case study presented in this paper has some limitations. First, the case was exploratory in nature and was relatively small scale. This limits the nature of the findings and a similar but more extensive longitudinal study would be useful. Second, as indicated above, the nature of the business sector studied meant that there was little opportunity to explore routines and rules in a dynamic environment. Third, the interviews were concentrated primarily around management accounting staff. Broader organisational interviews would enhance the evidence reported here, but such interviews were not forthcoming in Engineering Ltd based on the access agreed.

Despite these limitations, this paper presents empirical evidence of simultaneous stability and change in a management accounting practice. The management accounting practice which was the focus of the study was standard costing, which may be perceived as a very traditional, stable practice, and the analysis revealed that such a practice can embody change - albeit in a way which underpins the existing ways of doing things (i.e. the ostensive routine). Thus, the paper also contends that while new management accounting practices may be de rigueur, traditional management accounting practices are worthy of further study in the efforts to delve more deeply into the concepts of routines and rules in management accounting.

\section{REFERENCES}

Atkinson, A.A. and Shaffir, W. (1998). Standards for Field Research in Management Accounting, Journal of Management Accounting Research, Vol. 10, pp. 41-68.

Becker, M. (2004). Organisational Routines: A Review of the Literature, Industrial and Corporate Change, Vol. 13, No. 4, pp. 643-677.

Becker, M. (2005). The Concept of Routines: Some Clarifications, Cambridge Journal of Economics, Vol. 29, No. 2, pp. 249-262.

Bhimani, A. and Bromwich, M. (2010). Management Accounting: Retrospect and Prospect, London: Elsevier.

Booth, P., Matolcsy, Z. and Wieder, B. (2000). The Impacts of Enterprise Resource Planning Systems on Accounting Practice - The Australian Experience, Australian Accounting Review, Vol. 10, No. 2, pp. 4-18. 
Bruggeman, W. and Slagmulder, R. (1995). The Impact of Technological Change on Management Accounting, Management Accounting Research, Vol. 6, No. 3, pp. 214-252.

Burns, J. and Baldvinsdottir, G. (2005). An Institutional Perspective of Accountants' New Roles - An Interplay of Contradictions, European Accounting Review, Vol. 14, No. 4, pp. 725-757.

Burns, J. and Scapens, R. (2000). Conceptualizing Management Accounting Change: An Institutional Framework, Management Accounting Research, Vol. 11, No. 1, pp. 3-25.

Burns, J. and Vaivio, J. (2001). Management Accounting Change, Management Accounting Research, Vol. 12, No. 4, pp. 389-402.

Caglio, A. (2003). Enterprise Resource Planning Systems and Accountants: Towards Hybridization, European Accounting Review, Vol. 12, No. 1, pp. 123-153.

Chartered Institute of Management Accountants (2009). Management Accounting Survey: 2009 Results, CIMA Global, available from: <http://www.cimaglobal.com/ Thought-leadership/Research-topics / Management-accounting-in-different-sectors/ Management-accounting-survey/>, accessed 15 May 2013.

Clarke, P. (1997). Management Accounting Practices in Large Irish Manufacturing Firms, Irish Business and Administrative Research, Vol. 18, pp. 136-152.

Coad, A. and Herbert, I. (2009). Back to the Future: New Potential for Structuration Theory in Management Accounting Research?, Management Accounting Research, Vol. 20, No. 3, pp. 177-192.

Collier, P.M. (2001). The Power of Accounting: A Field Study of Local Financial Management in a Police Force, Management Accounting Research, Vol. 12, No. 4, pp. 465-486.

Dillard, J.F., Rigsby, J.T. and Goodman, C. (2004). The Making and Remaking of Organization Context, Accounting, Auditing and Accountability Journal, Vol. 17, No. 4, pp. 506-542.

Englund, H. and Gerdin, J. (2008). Structuration Theory and Mediating Concepts: Pitfalls and Implications for Management Accounting Research, Critical Perspectives on Accounting, Vol. 19, No. 8, pp. 1122-1134.

Feldman, M. and Pentland, B. (2003). Re-Conceptualizing Organisational Routines as a Source of Flexibility and Change, Administrative Science Quarterly, Vol. 48, No. 1, pp. 94-118.

Fleischman, R.K. and Tyson, T.N. (1998). The Evolution of Standard Costing in the U.K. and U.S.: From Decision Making to Control, Abacus, Vol. 34, No. 1, pp. 92-119.

Fry, T.D., Steele, D.C. and Saladin, B.A. (1998). The Use of Management Accounting Systems in Manufacturing, International Journal of Production Research, Vol. 36, No. 2, pp. 503-525.

Granlund, M. and Malmi, T. (2002). Moderate Impact of ERPS on Management Accounting: A Lag or Permanent Outcome?, Management Accounting Research, Vol. 13, No. 3, pp. 299-321.

Guilding, C., Lamminmaki, D. and Drury, C. (1998). Budgeting and Standard Costing Practices in New Zealand and the United Kingdom, International Journal of Accounting, Vol. 33, No. 5, pp. 569-588.

Hodgson, G. (2006). What Are Institutions?, Journal of Economic Issues, Vol. XL, No. 1, pp. $1-25$.

Hodgson, G. (2008). The Concept of a Routine in M. Becker (ed.), Handbook of Organisational Routines, pp. 15-28, Cheltenham: Edward Elgar.

Jack, L. and Kholeif, A. (2008). Enterprise Resource Planning and a Contest to Limit the Role of Management Accountants: A Strong Structuration Perspective, Accounting Forum, Vol. 32, No. 1, pp. 30-45.

Jazayeri, M. and Hopper, T. (1999). Management Accounting within World Class Manufacturing, Management Accounting Research, Vol. 10, No. 3, pp. 263-301.

Johnson, H.T. and Kaplan, R.S. (1987). Relevance Lost: The Rise and Fall of Management Accounting, Boston, MA: Harvard Business School Press. 
Quinn, Flood and Lynch

Kranowski, N. (1977). The Historical Development of Standard Costing until 1920, Journal of Accountancy, Vol. 144, No. 6, pp. 66-73.

Lukka, K. (2007). Management Accounting Change and Stability: Loosely Coupled Rules and Routines in Action, Management Accounting Research, Vol. 18, No. 1, pp. 76-101.

MacIntosh, N.B. and Scapens, R.W. (1990). Structuration Theory in Management Accounting, Accounting, Organisations and Society, Vol. 15, No. 5, pp. 455-477.

MacIntosh, N.B. and Scapens, R.W. (1991). Management Accounting and Control Systems: A Structuration Theory Analysis, Journal of Management Accounting Research, Vol. 2, pp. 131-158.

Modell, S. (2003). Goals versus Institutions: The Development of Performance Measurement in the Swedish University Sector, Management Accounting Research, Vol. 14, No. 4, pp. 333-359.

Monden, Y. and Sakurai, M. (1989). Japanese Management Accounting: A World Class Approach to Profit Management, Cambridge, MA: Productivity Press.

Morgen, J. and Olsen, W. (2011). Conceptual Issues in Institutional Economics: Clarifying the Fluidity of Rules, Journal of Institutional Economics, Vol. 7, No. 3, pp. 425-454.

Nor-Aziah, A.K. and Scapens, R. (2007). Corporatisation and Accounting Change: The Role of Accountants in a Malaysian Public Utility, Management Accounting Research, Vol. 18, No. 2, pp. 209-247.

Oliveira, J. (2011). Bringing Power, Interests and Rules to OIE: A Model of Rule-Based Action, paper presented at the 8th ENROAC Conference, 1-3 June, Lisbon.

Oliveira, J. and Quinn, M. (2012). Re-Thinking and Re-Balancing Rules and Routines: A Framework on Institutionalisation Processes in Management Accounting, unpublished working paper.

Otley, D. (1985). Developments in Management Accounting Research, British Accounting Review, Vol. 17, No. 2, pp. 3-23.

Otley, D. (2008). Did Kaplan and Johnson Get It Right?, Accounting, Auditing and Accountability Journal, Vol. 21, No. 2, pp. 229-239.

Pentland, B. (2011). The Foundation Is Solid, if You Know Where to Look: Comment on Felin and Foss, Journal of Institutional Economics, Vol. 7, No. 2, pp. 279-293.

Pentland, B. and Feldman, M. (2005). Organisational Routines as a Unit of Analysis, Industrial and Corporate Change, Vol. 14, No. 5, pp. 793-815.

Pentland, B. and Feldman, M. (2008). Issues in Field Studies of Organisational Routines in M. Becker (ed.), Handbook of Organisational Routines, pp. 281-300, Cheltenham: Edward Elgar.

Pentland, B., Haerem, T. and Hillison, D. (2010). Comparing Organisational Routines as Recurrent Patterns of Action, Organisation Studies, Vol. 31, No. 7, pp. 917-940.

Pierce, B. and O'Dea, W.A. (1998). An Empirical Study of Management Accounting Practices in Ireland, Irish Accounting Review, Vol. 5, No. 2, pp. 35-65.

Quinn, M. (2010). Continuity and Change in Management Accounting: Evidence from the Corrugated Container Sector, unpublished PhD thesis, University of Dundee.

Quinn, M. (2011). Routines in Management Accounting: Some Further Exploration, Journal of Accounting and Organisational Change, Vol. 7, No. 4, pp. 337-357.

Reynaud, B. (2005). The Void at the Heart of Rules: Routines in the Context of Rule-Following. The Case of the Paris Metro Workshop, Industrial and Corporate Change, Vol. 14, No. 5, pp. 847-871.

Scapens, R. (2004). Doing Case Study Research in C. Humphrey and B. Lee (eds), The Real Life Guide to Accounting Research: A Behind-the-Scenes View of Using Qualitative Research Methods, pp. 257-279, Oxford: Elsevier. 
Scapens, R. and Bromwich, M. (2010). Management Accounting Research: 20 Years On, Management Accounting Research, Vol. 21, No. 4, pp. 278-284.

Scapens, R. and Jazayeri, M. (2003). ERP Systems and Management Accounting Change: Opportunities or Impacts? A Research Note, European Accounting Review, Vol. 12, No. 1, pp. 201-233.

Scapens, R. and Roberts, J. (1993). Accounting and Control: A Case Study of Resistance to Accounting Change, Management Accounting Research, Vol. 4, No. 1, pp. 1-32.

Seal, W. (2006). Management Accounting and Corporate Governance: An Institutional Interpretation of the Agency Problem, Management Accounting Research, Vol. 17, No. 4, pp. 389-408.

Searle, J. (2005). What Is an Institution?, Journal of Institutional Economics, Vol. 1, No. 1, pp. $1-22$.

Siti-Nabiha, A.K. and Scapens, R. (2005). Stability and Change: An Institutionalist Study of Management Accounting Change, Accounting, Auditing and Accountability Journal, Vol. 18, No. 1, pp. 44-73.

Soin, K., Seal, W. and Cullen, J. (2002). ABC and Organisational Change: An Institutional Perspective, Management Accounting Research, Vol. 13, No. 2, pp. 249-271.

Sulaiman, S. and Mitchell, F. (2005). Utilising a Typology of Management Accounting Change: An Empirical Analysis, Management Accounting Research, Vol. 16, No. 4, pp. 422-437.

Tsamenyi, M., Cullen, J. and Gonzalez, J. (2006). Changes in Accounting and Financial Information Systems in a Spanish Electricity Company: A New Institutional Theory Analysis, Management Accounting Research, Vol. 17, No. 4, pp. 389-408.

van der Steen, M. (2009). Inertia and Management Accounting Change, Accounting, Auditing and Accountability Journal, Vol. 22, No. 5, pp. 736-761.

van der Steen, M. (2011). The Emergence and Change of Management Accounting Routines, Accounting, Auditing and Accountability Journal, Vol. 24, No. 4, pp. 502-547.

Volkoff, O., Strong, D.M. and Elmes, M.B. (2007). Technological Embeddedness and Organisational Change, Organisation Science, Vol. 18, No. 5, pp. 832-848.

Vromen, J. (2011). Routines as Multilevel Mechanisms, Journal of Institutional Economics, Vol. 7, No. 2, pp. 175-196.

Winter, S. (1995). Four Rs of Profitability: Rents, Resources, Routines and Replication in C. Montgomery (ed.), Resource-Based and Evolutionary Theories of the Firm: Towards a Synthesis, pp. 147-178, Boston, MA: Kluwer.

Yazdifer, H., Zaman, M., Tsamenyi, M. and Askarany, D. (2008). Management Accounting Change in a Subsidiary Organisation, Critical Perspectives on Accounting, Vol. 19, No. 3, pp. 404-430.

Yin, R.K. (2003), Case Study Research: Design and Methods, Thousand Oaks, CA: Sage Publications.

Zoysa, D.A. and Herath, S.K. (2007). Standard Costing in Japanese Firms, Industrial Management and Data Systems, Vol. 107, No. 2, pp. 271-283. 